\title{
STATUS HUKUM PERKAWINAN BAWAH TANGAN MENURUT HUKUM NASIONAL INDONESIA (Suatu Telaah Normatif)
}

\author{
Jamil
}

Dosen Kopertais DPK STAI Yapnas Jeneponto, PNS Kemenag dan Mahasiswa Program Doktor Ilmu Hukum Islam UIN Alauddin Makassar

\begin{abstract}
Marriage under his hand, is marriage between a man and a woman, who met the pillars and the conditions set out in the law of each and legislation, but not recorded in government agencies who are in authority, the Office religion (KUA) District of the Moslems or the Civil Registry Office (KCP) for persons professing the religion other than Islam. The legal status of marriage under his hand, both in terms of religion and legislation, is a marriage of allowed / legal under Indonesian national law, thus binding on the parties to do so and any legal consequences on children and property from the marriage.
\end{abstract}

Keywords:

Hands Down Marriage, Legal Status

\begin{abstract}
Abstrak
Perkawinan bawah tangan, adalah perkawinan antara seorang lakilaki dan seorang perempuan, yang terpenuhi rukun-rukun dan syaratsyarat yang ditetapkan dalam hukum agama masing-masing dan peraturan perundang-undangan, namun tidak dicatat pada instansi pemerintah yang berwewenang, yakni Kantor Urusan Agama (KUA) Kecamatan bagi orang yang beragama Islam atau Kantor Catatan Sipil (KCP) bagi orang yang beragama selain Islam. Status hukum perkawinan bawah tangan, baik dilihat dari sisi agama maupun peraturan perundang-undangan, adalah merupakan perkawinan yang dibolehkan/legal menurut hukum nasional Indonesia, sehingga mengikat para pihak yang melakukannya dan berakibat hukum terhadap anak dan harta benda dari perkawinan itu.
\end{abstract}

Kata Kunci:

Perkawinan Bawah Tangan, Status Hukum 


\section{A. PENDAHULUAN}

L

embaga perkawinan mengandung beberapa tujuan, yaitu untuk menegakkan agama, mendapatkan keturunan, mencegah maksiat, membina rumah tangga yang damai dan teratur. ${ }^{1}$ Sejalan dengan itu, dalam Undang-Undang Nomor 1 Tahun 1974 tentang Perkawinan (UU No. 1/1974), dirumuskan bahwa tujuan perkawinan adalah membentuk keluarga (rumah tangga) yang bahagia dan kekal berdasarkan Ketuhanan Yang Maha Esa. ${ }^{2}$ Ini berarti bahwa perkawinan memiliki kedudukan yang sentral dalam kehidupan manusia baik sebagai individu maupun komunal. Karena itu, pantas kalau perkawinan dipandang sebagai dasar dari peradaban umat manusia. ${ }^{3}$

Keluarga atau rumah tangga kekal dan bahagia mencerminkan beberapa aspek: Pertama, aspek prokreatif, yaitu hubungan suami isteri yang dibina berdasarkan hak dan kewajiban antara suami dan isteri. Kedua, aspek rekreatif, yaitu rumah tangga dibina untuk memperoleh kesenangan, ketenangan, dan kenikmatan hidup. Rumah tangga yang dapat dibina ke arah itu, adalah rumah tangga yang dibina dengan dasar cinta kasih antara suami dan isteri. Ketiga, aspek regeneratif, yaitu rumah tangga yang dibina dengan tujuan untuk mendapatkan anak atau keturunan. Dan keempat, aspek relatif, yaitu rumah tangga yang dibina untuk membentuk relasi, memperkuat jaringan kekeluargaan, baik antara sesama suami isteri maupun dengan keluarganya masing-masing.

Menilik uraian di atas, dapat fahami bahwa perkawinan merupakan sarana bagi manusia untuk dapat meningkatkan kuantitas dan kualitas kehidupannya. Dengan demikian, manusia sangat bergantung pada lembaga perkawinan. Demikian pula dengan masyarakat Indonesia, yang terdiri dari kumpulan rumah tangga atau keluarga. Karena itu, sudah selayaknya kalau masyarakat Indonesia melindungi lembaga perkawinan dengan cara menempatkan pengaturannya dalam konstitusi negara, Undang-Undang Dasar 1945 (UUD 1945). Ini berarti bahwa hak asasi manusia di bidang perkawinan itu ada, diakui dan dilindungi. Konsekwensinya, adalah disamping bahwa setiap warga negara dijamin haknya oleh negara untuk membentuk keluarga melalui perkawinan, juga negara terlibat langsung dan bertanggungjawab untuk melindungi lembaga perkawinan.

Walaupun demikian, tidak berarti dengan serta-merta perkawinan dapat dilakukan secara bebas dan tanpa diskriminasi. Sejarah menunjukkan bahwa hingga abad ke-20, di Indonesia, selalu terdapat kasus yang menunjukkan bahwa tidak setiap orang bebas melakukan perkawinan. Akibat itu, telah mendorong banyak orang Indonesia melakukan perkawinan bawah tangan. Sebenarnya hingga

\footnotetext{
${ }^{1}$ Hilman Hadikusuma, Hukum Perkawinan Indonesia (Bandung: Mandar Maju, 1990), h. 24.

${ }^{2}$ UU No. 1/1974: Pasal 1.

${ }^{3}$ Kuntjoro Purbopranoto, Hak-Hak Azasi Manusia dan Pancasila, (Cet. V; Jakarta: Pradnya Paramita, 1976), h. 138.

${ }^{4}$ UUD 1945: Pasal 28 ayat (1) menyebutkanbahwa: setiap orang berhak membentuk keluarga dan melanjutkan keturunan melalui perkawinan yang sah dan bebas.
} 
sekarang, diskriminasi tersebut masih terjadi, terbukti dengan masih sering terjadinya calon suami isteri yang melakukan perkawinan di luar prosedur, ${ }^{5}$ seperti perkawinan bawah tangan ini.

Terlepas dari sah atau tidaknya, secara sosiologis perkawinan perkawinan bawah tangan merupakan fenomena sosial di Indonesia dan dibutuhkan oleh masyarakat, dan sulit untuk dihindari mengingat adanya keanekaragaman (plurality) dalam tubuh bangsa Indonesia itu sendiri baik dari segi suku, ras, sosial budaya, maupun agama 6 . Selain itu, adalah akibat daripada diakuinya Pancasila dan UUD 1945, di mana di dalamnya diakui tentang HAM termasuk mengenai kebebasan membentuk keluarga7, kebebasan untuk mendapatkan perlakuan, jaminan, perlindungan dan kepastian hukum yang adil serta perlakuan yang sama di hadapan hukum, ${ }^{8}$ dan kebebasan beragama. ${ }^{9}$ Dalam kondisi seperti itu niscaya akan terjadi interaksi sosial antara anggota masyarakat yang melampaui sekat-sekat itu, sehingga perkawinan bawah tangan akan selalu terjadi dan tidak mungkin dicegah.

Di masa lalu perkawinan bawah tangan tidak menjadi persoalan dalam masyarakat Indonesia, karena yang penting adalah sebuah perkawinan memenuhi rukun dan syarat menurut agama masing-masing. Sampai sekarang pun sebagian masyarakat masih banyak yang melakukannya. Salah satu bukti yang gamblang adalah, setiap ada perkawinan massal yang diadakan oleh pemerintah selalu saja banyak pasangan suami isteri yang mengikutinya, yang pada umumnya terdiri dari mereka yang telah beberapa lama hidup bersama sebagai suami isteri bahkan telah bercucu.

Berdasarkan deskripsi di atas, yang menjadi masalah dalam tulisan ini adalah bagaimana status hukum perkawinan bawah tangan menurut hukum nasional Indonesia? Masalah inilah yang akan dipaparkan dalam tulisn ini dengan menggunakan pendekatan yuridis-normatif. Adapun tujuan yang hendak dicapaidari tulisan ini, adalah untuk menelaah secara kritis kemudian memaparkan status hukum perkawinan bawah tangan dalam hukum nasional Indonesia.

\section{B. KONSEP PERKAWINAN BAWAH TANGAN DAN HUKUM NASIONAL INDONESIA}

\section{Konsep Perkawinan Bawah Tangan}

Sebelum pengertian perkawinan bawah tangan diutarakan, akan dikemukakan lebih dahulu secara selintas tentang pengertian perkawinan secara umum. Dari sini dapat diketahui, dimanakah perbedaan antara perkawinan bawah tangan dengan

\footnotetext{
5 Abdurrahman, Himpunan Peraturan Perundang-Undangan tentang Perkawinan (Cet. I; Jakarta: Akademika Pressindo, 1986), h. 26.

${ }^{6}$ Lihat UU No. 1/PNPS/1965.

${ }^{7}$ UUD 1945: Pasal 28B.

${ }^{8}$ UUD 1945: Pasal 28D.

9 UUD 1945: Pasal 29. Lihat pula Abdurrahman, Himpunan Peraturan Perundang-Undangan tentang Perkawinan, (Cet. I: Jakarta: Akademika Pressindo, 1986), h. 43.
} 
perkawinan pada umumnya yang biasa dikenal dalam masyarakat, atau janganjangan keduanya tidak ada perbedaan yang signifikan. Karena selama ini banyak orang mendiskusikan perkawinan bawah tangan, namun bukannya memberi kejelasan atau memperbaiki pemahaman orang tentang perkawinan bawah tangan, malah mengaburkannya. Hal ini disebabkan karena para pembicara tidak bisa mengambil jarak terhadap obyek diskusi, yaitu perkawinan bawah tangan, padahal itu diperlukan untuk dapat melihat secara obyektif dan proporsional duduk masalahnya.

Perkawinan berasal dari kata kawin, yang berarti perjodohan antara laki-laki dan perempuan menjadi suami isteri atau berarti nikah. ${ }^{10}$ Kata kawin kemudian mendapat tambahan awalan per dan akhiran an, kemudian membentuk kata majemuk menjadi perkawinan yang berarti pernikahan; perayaan (urusan dan sebagainya) kawin. ${ }^{11}$

Secara terminologis, terdapat banyak pengertian perkawinan. Di antaranya, seperti dalam UU No. 1/1974, yang di dalamnya dirumuskan sebagai "ikatan lahir bathin, antara seorang pria dengan seorang wanita sebagai suami isteri dengan tujuan membentuk keluarga (rumah tangga) yang bahagia dan kekal bersdasarkan Ketuhanan Yang Maha Esa". ${ }^{12}$ K. Wantjik Saleh memberikan pengertian perkawinan sebagai "suatu perjanjian yang diadakan oleh dua orang, dalam hal ini perjanjian antara seorang pria dengan seorang wanita dengan tujuan material, yakni membentuk keluarga (rumah tangga) yang bahagia dan kekal berdasarkan ketuhanan Yang Maha Esa...". ${ }^{13}$ Sedangkan Abdullah Siddik memberikan pengertian perkawinan sebagai "pertalian yang sah antara seorang laki-laki dengan seorang perempuan yang hidup bersama (bersetubuh) dan yang tujuannya membentuk keluarga dan melanjutkan keturunan, serta mencegah perzinahan dan menjaga ketentraman jiwa". ${ }^{14}$

Pengertian-pengertian perkawinan di atas, tampak perbedaan satu sama lain. Perbedaan itu tidak lain disebabkan oleh karena perkawinan sebagai suatu lembaga sosial mempunyai banyak segi dan dapat dilihat dari berbagai sudut pandang, misalnya hukum, agama, dan sosial. Meskipun demikian dapat disimpulkan bahwa dari sisi konstruksi hukum, perkawinan merupakan perjanjian yang diadakan oleh seorang pria dengan seorang wanita dengan tujuan untuk membentuk rumah tangga yang bahagia dan kekal. Dengan demikian, perkawinan merupakan perbuatan hukum yang memiliki unsur-unsur sebagai berikut: (1) adanya suatu hubungan hukum (perjanjian); (2) antara seorang pria dan seorang wanita; (3) untuk membentuk keluarga atau rumah tangga; (4) untuk waktu yang lama atau kekal; (5) dengan tujuan tertentu.

\footnotetext{
${ }^{10}$ W.J.S. Poerwadarminta, Kamus Umum Bahasa Indonesia, (Jakarta: Balai Pustaka, 1985), h. 453.

${ }^{11}$ W.J.S. Poerwadarminta, Kamus Umum Bahasa Indonesia, h. 453.

12 UU No. 1/1974: Pasal 1.

${ }^{13}$ K. Wantjik Saleh, Hukum Perkawinan Indonesia, (Cet. IV; Jakarta: Ghalia Indonesia, 1978), h. 14.

${ }^{14}$ Abdullah Siddik, Hukum Perkawinan Islam, (Jakarta: Tinta Mas Indonesia, 1983), h. 25.
} 
Sementara itu, istilah perkawinan bawah tangan sendiri sebenarnya baru dikenal sejak pemerintah menerbitkan UU No. 1/1974 yang diberlakukan tanggal 1 April 1975 melalui Peraturan Pemerintah Nomor 9 Tahun 1975 Tentang Pelaksanaan UU No. 1 Tahun 1974 (PP No. 9/1975). Sebelumnya, istilah perkawinan bawah tangan tidak dikenal dalam masyarakat Indonesia.

Dalam perundang-undangan tidak ditemukan rumusan pengertian perkawinan bawah tangan, namun istilah ini sudah tidak asing lagi dalam masyarakat Indonesia. Artinya, secara yuridis perkawinan bawah tangan tidak mendapat pengaturan secara eksplisit dalam perundang-undangan, tetapi secara faktual sudah merupakan suatu kenyataan dalam masyarakat Indonesia. Fenomena perkawinan bawah tangan telah lama terjadi dan semakin terbuka dilakukan oleh warga masyarakat, terutama setelah dikeluarkan fatwa Majelis Ulama Indonesia (MUI) yang menyahkan pernikahan bawah tangan tersebut. ${ }^{15}$

Istilah yang digunakan masyarakat untuk mengidentifikasi perkawinan bawah tangan sebenarnya tidak tunggal. Selain istilah perkawinan bawah tangan, juga digunakan istilan nikah sirri. Istilah perkawinan bawah tangan sendiri digunakan oleh Komisi Fatwa MUI. Tujuannya dapat diduga, selain untuk membedakannya dengan nikah sirri yang sudah dikenal masyarakat, juga karena istilah ini dianggap lebih sesuai dengan ketentuan agama Islam dan hukum yang berlaku.

Tetapi apakah yang dimaksudkan dengan perkawinan bawah tangan itu? Secara literal, perkawinan bawah tangan difahami sebagai perkawinan yang tidak dihadiri oleh pegawai pemerintah yang berwewenang mencatat peristiwa perkawinan atau perkawinan yang tidak dicatat pada instansi pemerintah yang berwewenang untuk itu. Dan akibat dari pelaksanaannya yang demikian, pasangan suami isteri yang melakukannya tidak memiliki Akta Nikah sebagai bukti tertulis dari perkawinannya. ${ }^{16}$

Secara terminologis, Idris Romulyo memberikan pengertian perkawinan bawah tangan sebagai “... suatu perkawinan yang dilakukan oleh orang-orang Islam Indonesia, memenuhi baik rukun-rukun maupun syarat-syarat perkawinan, tetapi tidak didaftarkan untuk dicatat pada pejabat pencatat nikah, seperti diatur dalam Undang-undang Nomor 1 Tahun 1974". ${ }^{17}$ Sementara KH. Ma'ruf Amin memberikan pengertian perkawinan bawah tangan sebagai berikut, yaitu "suatu perkawinan antara seorang laki-laki dan seorang perempuan yang tidak memenuhi Pasal 2 ayat

${ }^{15}$ Fatwa MUI yang menyahkan praktik perkawinan bawah tangan di Indonesia, dihasilkan dari Forum Ijtima' Ulama se-Indonesia II tahun 2006 yang dihadiri oleh lebih dari 1000 orang ulama dari berbagai unsur di Indonesia. Acara tersebut digelar di Kompleks Pondok Modern Darussalam Gontor, Pacitan, Jawa Timur.Lihat http://www.mui.or.id

${ }^{16}$ Mohd Idris Ramulyo, Hukum Perkawinan, Hukum Kewarisan, Hukum Acara Peradilan Agama dan Zakat Menurut Hukum Islam, (Cet. III; Jakarta: Sinar Grafika, 2004), h. 21.

${ }^{17}$ Mohd. Idris Ramulyo, Hukum Perkawinan, Hukum Kewarisan, Hukum Acara Peradilan Agama dan Zakat Menurut Hukum Islam, h. 41. 
(2) UU No. 1 Tahun 1974 dan tata cara perkawinan menurut PP No. 9 Tahun 1975". ${ }^{18}$ MUI sendiri melalui fatwanya yang dimaksud memberikan pengertian perkawinan bawah tangan, sebagai "pernikahan yang terpenuhi semua rukun dan syarat yang ditetapkan dalam fikih (hukum Islam) namun tanpa pencatatan resmi di instansi berwewenang sebagaimana diatur oleh peraturan perundang-undangan yang berlaku". ${ }^{19}$ Jadi, tidak dicatatnya perkawinan ini pada instansi pemerintah yang berwewenang untuk itu, menjadi pembeda dari perkawinan pada umumnya. Hal ini disebabkan karena dalam UU No. 1/1974 terdapat klausul tentang pencatatan perkawinan, ${ }^{20}$ yang oleh sebagian orang memahaminya bahwa pencatatan perkawinan itu merupakan kewajiban.

Dari aspek konstruksi hukum, perkawinan bawah tangan dapat difahami sebagai perkawinan yang terpenuhi rukun-rukun dan syarat-syarat yang ditetapkan dalam hukum agama masing-masing dan peraturan perundang-undangan, namun tidak dicatat pada instansi pemerintah yang berwewenang, yakni Kantor Urusan Agama (KUA) Kecamatan bagi orang yang beragama Islam atau Kantor Catatan Sipil (KCP) bagi orang yang beragama selain Islam. Akibat tidak dicatat itulah sehingga bagi pasangan yang melakukan perkawinan bawah tangan tidak memiliki Akta Nikah atas perkawinannya.

Terdapat faktor-faktor yang mendorong orang Indonesia melakukan perkawinan bawah tangan. Salah satu di antaranya adalah keinginan laki-laki atau suami untuk memiliki isteri lebih dari satu orang, dan ini merupakan faktor yang umum terjadi. Sementara perkawinan yang kedua atau lebih bagi seorang laki-laki bukan persoalan mudah, khususnya di Indonesia, karena harus memenuhi syaratsyarat eksternal-prosedural yang banyak sehingga untuk memenuhinya memerlukan waktu yang panjang dan biaya yang tidak sedikit, dan karena itu bagi sebagian pelaku perkawinan bawah tangan dipandang tidak efisien. Faktor lain, adalah keterbatasan ekonomi yang dialami laki-laki, karena dalam praktik bukan saja biaya pencatatan perkawinan yang mereka harus keluarkan tetapi juga biaya resepsinya yang relatif jauh lebih mahal tergantung adat istiadat masyarakat di mana calon pelaku perkawinan bawah tangan berdomisili. Dengan demikian, dapat difahami bahwa perkawinan bawah tangan itu tidak berdiri sendiri, melainkan ditumbuhkan oleh kondisi dan adat istiadat yang berkembang dalam masyarakat Indonesia sendiri.

\section{Hukum Nasional Indonesia}

Hukum nasional Indonesia, dapat dijelaskan setelah lebih dahulu memahami makna kata hukum nasional dan hukum nasional Indonesia itu sendiri. Hukum nasional menurut Mochtar Kusumaatmadja seperti dikutip oleh Bernard Arief

${ }^{18}$ KH. Ma'ruf Amin, Ketua Panitia Pengarah Ijtima’ Ulama Komisi Fatwa MUI se Indonesia II. Lihat www.hukumonline.com

${ }^{19}$ Lihat http://www.mui.or.id

${ }^{20}$ UU No. 1/1974: Pasal 2 ayat (2). 
Sidharta, merupakan keseluruhan asas-asas hukum, aturan-aturan hukum tertulis dan tidak tertulis, pranata-pranata hukum serta putusan-putusan hukum yang tersusun dan saling berkaitan sehingga mewujudkan satu kesatuan yang relatif utuh. ${ }^{21}$ Sistem hukum dalam arti ini oleh Mochtar disebut "tata hukum" yang pada dasarnya merupakan produk interaksi antara kesadaran hukum dan proses politik. ${ }^{22}$

Apakah yang dimaksud dengan tata hukum? R. Abdoel Djamali mengartikan tata hukum (Belanda: recht orde) dengan "memberikan tempat yang sebenarnya pada hukum", atau "susunan norma hukum". ${ }^{23}$ Sudiman Kartohadiprodjo mengartikan tata hukum sebagai "hukum yang sekarang berlaku"; "berlaku" berarti yang memberi akibat hukum kepada peristiwa-peristiwa dalam pergaulan hidup; "sekarang" menunjukkan kepada pergaulan hidup yang ada pada saat ini, dan tidak kepada pergaulan hidup yang telah lampau, juga tidak kepada pergaulan hidup masa yang akan datang. ${ }^{24}$ SementaraMohammad Daud Ali memberikan arti tata hukum sebagai suatu susunan atau sistem hukum di suatu daerah atau negara tertentu..$^{25}$

Kalau disebut tata hukum berarti mengenai keberlakuan hukum. Keberlakuan hukum, dalam kepustakaan Ilmu Hukum dikenal dengan istilah geldingrecht (Belanda), yang berarti hukum yang berlaku. ${ }^{26}$ Hukum yang berlaku berarti pula hukum yang memberi akibat hukum kepada subyek hukum. Tetapi NE. Algra dan K. van Duyvendak berpendapat bahwa istilah lain untuk hukum yang berlaku itu adalah hukum positif. ${ }^{27}$ Sementara Bruggink menggunakan istilah keabsahan atau validitas (geldigheid) dan keberlakuan (gelding) sebagai sinonim. ${ }^{28}$

Ada beberapa macam keberlakuan hukum yang telah dikenal. Urlich Klug membagi keberlakuan hukum ke dalam sembilan macam, yaitu: (1) keberlakuan yuridis; (2) keberlakuan etis; (3) keberlakuan ideal; (4) keberlakuan riil; (5) keberlakuan ontologis; (6) keberlakuan sosio-relatif; (7) keberlakuan dekoratif; (8)

21 Lihat Bernard Arief Sidharta, Refleksi Tentang Struktur Ilmu Hukum (Sebuah Penelitian Tentang Fundasi Kefilsafatan dan Sifat Keilmuan Ilmu Hukum Sebagai Landasan Pengembangan Ilmu Hukum Nasional Indonesia), (Cet. II; Bandung: Mandar Maju, 2000), h. 76.

22 Bernard Arief Sidharta, Refleksi Tentang Struktur Ilmu Hukum (Sebuah Penelitian Tentang Fundasi Kefilsafatan dan Sifat Keilmuan Ilmu Hukum Sebagai Landasan Pengembangan Ilmu Hukum Nasional Indonesia), h. 76.

${ }^{23}$ R. Abdoel Djamali, Pengantar Hukum Indonesia, (Edisi Revisi/Cet. XVII; Jakarta: PT. RajaGrafindo Persada, 20011), h. 5.

${ }^{24}$ Sudiman Kartohadiprodjo, Pengantar Tata Hukum di Indonesia, Jilid I, (Jakarta: PT. Pembangunan, 2004), h. 46.

${ }^{25}$ Mohammad Daud Ali, Hukum Islam: Pengantar Ilmu Hukum dan Tata Hukum Islam di Indonesia, (Cet. XVI; Jakarta: PT. RajaGrafindo Persada, 2011), h. 231.

26 JJH. Bruggink, Rechtsreflecties, Grondbegrippen uit de Rechtstheorie, diterjemahkan oleh Arief Sidharta, dengan judul: Refleksi Tentang Hukum, (Cet. II; Bandung: PT. Citra Aditya Bakti, 1999), h. 142.

${ }^{27}$ Lihat JJH. Bruggink, Rects Reflecties, Grondbegprippen uit de Rechtstheorie, diterjemahkan oleh Arief Sidharta, SH., dengan judul: Refleksi tentang Hukum, h. 143.

28 JJH. Bruggink, Rects Reflecties, Grondbegprippen uit de Rechtstheorie, diterjemahkan oleh Arief Sidharta, SH., dengan judul: Refleksi tentang Hukum, h. 147. 
keberlakuan estetis; dan (9) keberlakuan logikal. ${ }^{29}$ Sementara Bruggink membagi keberlakuan hukum hanya dalam tiga macam, yaitu: (1) keberlakuan faktual atau empiris kaidah hukum, yaitu jika para warga masyarakat, untuk siapa kaidah hukum itu berlaku, mematuhi kaidah hukum tersebut; (2) keberlakuan normatif atau formal kaidah hukum, yaitu jika suatu kaidah hukum itu merupakan bagian dari suatu sistem kaidah hukum tertentu yang di dalamnya kaidah-kaidah hukum itu saling menunjuk yang satu terhadap yang lain; (3) keberlakuan evaluatif kaidah hukum, yaitu jika kaidah hukum itu berdasarkan isinya dipandang bernilai. ${ }^{30}$ Namun apapun cara pembagian yang dilakukan, satu hal yang harus menjadi pegangan, bahwa hukum yang berlaku berarti yang memberi akibat hukum kepada peristiwa-peristiwa hukum dalam pergaulan hidup masyarakat.

Dengan demikian dapat difahami, bahwa istilah hukum nasional sinonim dengan tata hukum dan hukum positif, yaitu hukum yang sekarang berlaku dalam suatu negara, yang berarti yang memberi akibat hukum kepada peristiwa-peristiwa dalam pergaulan hidup sekarang dalam suatu negara itu. Atau susunan norma hukum yang memberi akibat hukum kepada subyek hukum dalam suatu negara itu sekarang.

Sementara istilah hukum nasional Indonesia, oleh Sunaryati Hartono diartikan sebagai hukum atau peraturan perundang-undangan yang didasarkan kepada ideologi dan konstitusi negara, yaitu Pancasila dan UUD 1945. ${ }^{31}$ M. Sularno memberikan pengertian hukum nasional Indonesia sebagai hukum atau peraturan perundang-undangan yang didasarkan kepada landasan ideologi dan konstitusi negara, yakni Pancasila dan UUD 1945, atau hukum yang dibangun di atas cita rasa dan rekayasa bangsa sendiri, yang bersumber dari nilai budaya bangsa yang sudah lama ada dan berkembang sekarang. ${ }^{32}$ Agak berbeda dengan yang lain, Kodiran mengartikan hukum nasional Indonesia sebagai sistem hukum yang timbul sebagai buah dari budaya rakyat Indonesia yang berjangkauan nasional, yaitu sistem hukum yang berlaku meliputi seluruh rakyat sejauh batas-batas nasional negara Indonesia. ${ }^{33}$

Berdasarkan definisi-definisi di atas, maka hukum nasional Indonesia dapat difahami sebagai keseluruhan norma hukum dan aturan hukum yang kait-mengait satu sama lain yang bersumber dari Pancasila dan UUD 1945, yang berlaku terhadap seluruh rakyat Indonesia dan di seluruh wilayah Indonesia. Keseluruhan norma dan aturan hukum tersebut dalam implementasinya diwujudkan dalam beberapa bentuk

\footnotetext{
${ }^{29}$ Lihat JJH. Bruggink, Rects Reflecties, Grondbegprippen uit de Rechtstheorie, diterjemahkan oleh Arief Sidharta, SH., dengan judul: Refleksi tentang Hukum, h. 148-149.

30 JJH. Bruggink, Rects Reflecties, Grondbegprippen uit de Rechtstheorie, diterjemahkan oleh Arief Sidharta, SH., dengan judul: Refleksi tentang Hukum, h. 149-152.

31 CFG.SunaryatiHartono, Politik Hukum Menuju Satu Sistem Hukum Nasional, (Cet. I; Bandung: Alumni, 1991), h.64.

${ }^{32}$ M. Sularno, "Syari'at Islam dan Upaya Pembentukan Hukum Positif di Indonesia”, dalam Majalah AlMawarid, Edisi XVI, Tahun 2006, h. 215.

${ }^{33}$ Kodiran, "Aspek Kebudayaan Bangsa dalam Hukum Nasional”, dalam Artidjo Alkostar (ed.), Identitas Hukum Nasional, (Yogyakarta: Fakultas Hukum UII, 1997), h. 87.
} 
yaitu undang-undang, yurisprudensi, kompilasi, dan fatwa. Ini berarti bahwa selain bersumber dari Pancasila dan UUD 1945, hukum nasional Indonesia tersebut mengikat dan memberi akibat hukum bagi subyek hukum di Indonesia baik orang (person) maupun badan hukum (recht person).

Meskipun pengertian-pengertian di atas menekankan keterkaitan struktural antara berbagai norma hukum dengan Pancasila dan UUD 1945, tidak berarti bahwa unsur-unsur dari luar hukum nasional Indonesia tidak ada. Hingga sekarang jelas sekali terlihat dalam hukum nasional Indonesia unsur-unsur luar itu. Apalagi bagi Indonesia yang sejarahnya pernah dijajah oleh negara-negaralain, seperti Belanda, yang menyebabkan hukum Barat khususnya Civil Law berlaku di Indonesia. Sebab setelah merdeka di tahun 1945, Indonesia tidak langsung mempunyai sistem hukum nasional yang bersumber dari tradisinya sendiri, sehingga masih menggunakan perundang-undangan peninggalan Pemerintah Hindia Belanda. Tetapi atas pertimbangan politik dan nasionalisme, perundang-undangan itu mengalami proses nasionalisasi, seperti penggantian nama dari Wetboek van Straafrechts menjadi Kitab Undang-undang Hukum Pidana, Burgerlijk Wetboek menjadi Kitab Undang-undang Hukum Perdata, Wetboek van Koophandel menjadi Kitab Undang-undang Hukum Dagang. Selain penggantian nama, beberapa di antara perundang-undangan peninggalan Pemerintah Hindia Belanda yang tidak sesuai lagi dengan kebutuhan Indonesia sebagai sebuah negara merdeka, berdaulat, dan religius turut pula diganti dan ditambahkan yang baru, di mana Proses ini disebut Jaspan sebagai penggantian atau penambahan peraturan hukum ad hoc satu persatu pada hukum kolonial. ${ }^{34}$ Penggunaan perundang-undangan warisan Pemerintah Hindia Belanda itu berdasarkan Pasal II Aturan Peralihan UUD 1945. Tujuannya ialah untuk menjaga kekosongan hukum (vacuum of law) di Indonesia yang baru memproklamirkan diri sebagi sebuah negara merdeka.

\section{STATUS HUKUM PERKAWINAN BAWAH TANGAN}

Untuk meraih tujuan yang amat besar (super goal) dari perkawinan seperti dipaparkan di atas, seyogyanya diskusi mengenai perkawinan bawah tangan, termasuk status hukumnya, harus dilakukan secara obyektif. Karena kalau tidak, bisa melahirkan stigma negatif bagi jenis perkawinan ini dan pelakunya di tengah masyarakat. Jika ke arah sana diskusinya, maka hal yang elementer untuk dilakukan adalah meneliti kaidah-kaidah hukum perkawinan yang berlaku dan memahaminya dengan menggunakan metodologi ilmiah yang sahih. Maksudnya, yang penting adalah bagaimana mendudukkan persoalan perkawinan bawah tangan secara proporsional pada ranah hukum dengan meneliti kaidah-kaidah hukum perkawinan yang berlaku itu, baik dari perundang-undangan, jurisprudensi, kompilasi, maupun

${ }^{34}$ MA. Jaspan, "Mencari Hukum Baru: Sinkretisme Hukum di Indonesia yang Membingungkan", dalam Mulyana W. Kusumah dan Paul S. Baut, Hukum, Politik dan Perubahan Sosial, (Jakarta: Yayasan Lembaga Bantuan Hukum Indonesia, 1988), h. 250-251. 
fatwa, khususnya mengenai perkawinan bawah tangan. Ini mutlak diperlukan mengingat perkawinan bawah tangan, sebagai telah dikemukakan, telah menjadi kenyataan dalam masyarakat Indonesia yang majemuk ini dan tidak mungkin untuk dicegah.

Ke arah sanalah tulisan ini dibawa, sehingga untuk melihat status hukum perkawinan bawah tangan dalam tata hukum Indonesia, perlu diadakan penelitian secara seksama, kritis, dan komprehensif tentang norma-norma hukum perkawinan yang berkenaan dengan perkawinan bawah tangan itu. Dalam kaitan ini, ada dua kategori norma hukum yaitu norma hukum agama dan peraturan perundangundangan. Keduanya menentukan status hukum perkawinan bawah tangan di Indonesia, yakni apakah boleh atau tidak boleh untuk dilakukan oleh warga negara Indonesia.

\section{Perkawinan Bawah Tangan Menurut Hukum Agama}

Sebelum tahun 1974, di Indonesia, berlaku beberapa peraturan perundangundangan yang dalam hal-hal tertentu saling bertentangan satu sama lain. Tetapi dengan diterbitkannya UU No. 1/1974 maka seluruh peraturan perkawinan yang tersebar itu dinyatakan tidak berlaku, kecuali terhadap masalah-masalah perkawinan yang materinya tidak diatur di dalam UU No. 1/1974 itu. Dengan demikian, UU No. 1/1974 berkedudukan sebagai undang-undang pokok mengenai hukum perkawinan di Indonesia, dan karena itu harus menjadi rujukan hukum dalam pelaksanaan perkawinan.

Mengacu pada undang-undang tersebut, hukum agama memegang peranan penting untuk menentukan kesahan suatu perkawinan. Dalam Pasal 2 ayat (1) UU No. 1/1974 dirumuskan bahwa perkawinan adalah sah, apabila dilakukan menurut hukum masing-masing agamanya dan kepercayaannya itu. Menurut penjelasan autentik pasal ini, tidak ada perkawinan yang dilakukan diluar hukum masingmasing agamanya dan kepercayaannya itu sesuai dengan UUD 1945. Oleh karena undang-undang tersebut menentukan kesahan sebuah perkawinan berdasarkan atau disandarkan kepada hukum masing-masing agamanya dan kepercayaannya itu, maka ini berarti bagi orang yang beragama Islam perkawinannya dilakukan menurut hukum agama Islam, sedangkan bahwa bagi orang yang beragama selain Islam adalah menurut hukum agama selain Islam pula. Dengan demikian, kedudukan hukum agama-agama merupakan hukum positif di Indonesia dalam bidang perkawinan, dan karena itu harus dilaksanakan.

Berdasarkan peraturan dalam pasal tersebut, maka sah tidaknya suatu perkawinan adalah semata-mata ditentukan oleh hukum agamanya dan kepercayaannya itu dari calon suami dan calon isteri yang hendak mengadakan perkawinan. Dengan demikian, perkawinan yang dilaksanakan bertentangan dengan ketentuan hukum agama, dengan sendirinya dianggap tidak sah dan tidak mempunyai akibat hukum sebagai suatu ikatan perkawinan. Dan hukum agama itu adalah hukum agama yang dimaksud dalam UU No. 1/PNPS/1965, yaitu agama 
Islam, agama Katholik, agama Kristen, agama Hindu, dan agama Buddha.

Namun demikian, dalam tulisan ini hanya hukum agama Islam tentang perkawinan bawah tangan yang dipaparkan, sementara hukum agama-agama lain akan diutarakan kemudian. Pilihan ini disebabkan karena di Indonesia orang Islamlah yang mayoritas dan dominan mewacanakan tentang sah atau tidaknya perkawinan bawah tangan, dan selalu dikaitkan dengan hukum agama Islam. Dan satu-satunya masalah sekitar perkawinan bawah tangan adalah tidak dicatatnya perkawinan ini pada instansi pemerintah yang berwewenang, seperti telah diutarakan di atas. Karena itu, yang penting untuk diketahui adalah bagaimanakah hukum pencatatan perkawinan menurut hukum agama Islam (hukum Islam), apakah wajib atau tidak.

Sementara itu, untuk meneliti hukum Islam, niscaya harus meneliti Alquran karena ia merupakan sumber primer dari hukum Islam, termasuk tentang pencatatan perkawinan. Seperti diketahui bahwa semua masalah yang dipandang besar, mendasar, dan luas dampaknya bagi kehidupan umat manusia diakomodir oleh Alquran, termasuk masalah perkawinan. Namun bagaimana dengan pencatatan perkawinan?

Di dalam Alquran tidak ditemukan klausul yang norma hukumnya dapat difahami sebagai perintah wajibnya mencatatkan peristiwa perkawinan. Satusatunya peristiwa hukum yang dilakukan oleh manusia yang disinggung oleh Alquran untuk dicatat adalah tentang kegiatan ekonomi khususnya transaksi utangpiutang, seperti yang disebutkan dalam QS. al-Baqarah: 282:

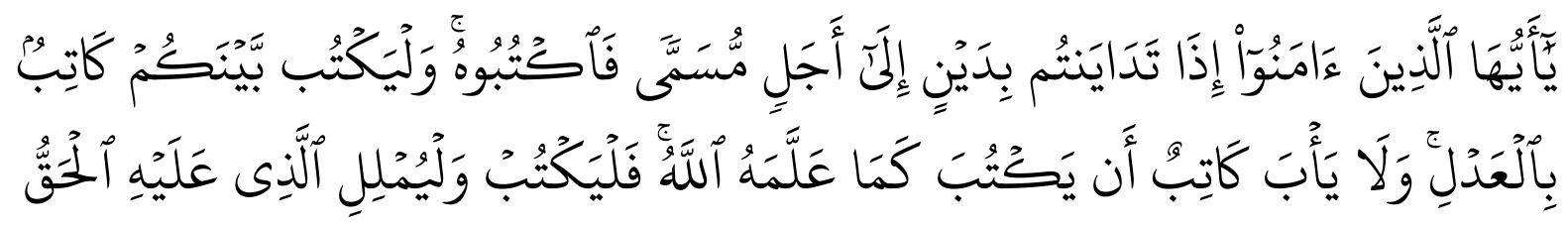

Terjemahnya:

Hai orang-orang yang beriman, apabila kamu bermu'amalah tidak secara tunai untuk waktu yang ditentukan, hendaklah kamu menuliskannya, dan hendaklah seorang penulis di antara kamu menuliskannya dengan benar, dan janganlah penulis enggan menuliskannya sebagaimana Allah mengajarkannya, maka hendaklah ia menulis, dan hendaklah orang yang berhutang itu mengimlakkan (apa yang akan ditulis itu) .....

Ada orang yang secara serampangan mengiyaskan hukum mencatat perkawinan kepada hukum mencatat utang-piutang, padahal itu tidak boleh karena tidak ada kesamaan atau kemiripan konstruksi hukum antara keduanya. Ahli hukum khususnya ahli usul fikih tentu faham betul hal itu. Apalagi kalau diingat bahwa kata faktubûhu dalam ayat di atas, ternyata difahami berbeda oleh para ulama. Ulama dari kalangan dzahiriyah mengatakan bahwa ayat ini menjadi dalil wajibnya mencatat transaksi utang-piutang, sementara mayoritas ulama dari kalangan hanafiyah, malikiyah, syafi'iyah, dan hanabilah berpendapat bahwa mencatat 
transaksi utang-piutang, hukumnya tidak wajib, tetapi perintah itu sifatnya hanya bimbingan agar manusia lebih berhati-hati dalam bertransaksi utang-piutang.

Berdasarkan penjelasan di atas, status hukum mencatatkan peristiwa perkawinan di dalam hukum Islam tidak diatur. Sesuatu yang hukumnya tidak diatur tidak dapat ketahui statusnya. Ini menunjukkan bahwa pencatatan perkawinan tidak terlalu urgen untuk dilakukan menurut hukum Islam. Karena itu, suami-isteri yang tidak mencatatkan perkawinannya tidak dalam keadaan melanggar hukum. Dengan demikian, yang dimaksud oleh Pasal 2 ayat (1) UU No. 1/1974 bahwa tidak adak ada perkawinan yang dilakukan di luar hukum masingmasing agamanya dan kepercayaannya itu, adalah menyangkut ruang lingkup rukun dan syarat sah perkawinan saja, bukan pencatatan perkawinan. Dari sini dapat disimpulkan bahwa perkawinan bawah tangan menurut hukum Islam merupakan perkawinan yang dibenarkan atau legal.

\section{Perkawinan Bawah Tangan Menurut Perundang-undangan}

Sekali lagi, bahwa istilah perkawinan bawah tangan sebenarnya hanya diberikan bagi perkawinan tidak dicatat, tetapi memenuhi rukun dan syarat berdasarkan hukum masing-masing agama dan kepercayaannya itu. Ada sementara orang yang menilai bahwa perkawinan bawah tangan dianggap tidak sah, namun di lain pihak sebagian menganggapnya sebagai perkawinan yang sah. Sampai sekarang, pada tataran pemikiran, persoalan perkawinan bawah tangan diperselisihi orang, termasuk para ulama, mengenai status hukumnya. Ada yang mengharamkan yang berarti menganggapnya tidak legal, namun ada pula yang menghalalkannya yang berarti menganggapnya legal. Menurut KH. Ma'ruf Amin, bahwa di kalangan ulama Indonesia saja perbedaan ini terjadi, ada ulama yang mengharamkan dan ada pula yang menghalalkannya. ${ }^{35}$ Bagi orang yang menganggap perkawinan bawah tangan dianggap tidak sah, mengatakan bahwa pernikahan tersebut tidak barokah dan luput dari perlindungan hukum perkawinan. ${ }^{36}$ Namun bagi orang yang menganggapnya legal, beralasan bahwa Pasal 2 ayat (1) UU No. 1/1974 menentukan bahwa perkawinan adalah sah apabila dilakukan menurut hukum masing-masing agama dan kepercayaannya itu, bukan karena dicatatnya.

Tetapi bagaimanakah sesungguhnya status hukum perkawinan bawah tangan berdasarkan hukum nasional Indonesia, apakah boleh atau legal, atau tidak? Kalau mengacu kepada UU No. 1/1974 sebagai undang-undang induk hukum kekeluargaan nasional Indonesia, pencatatan perkawinan disebutkan dalam Pasal 2 ayat (2), yang berbunyi bahwa "tiap-tiap perkawinan dicatat menurut peraturan perundang-undangan yang berlaku". Tidak seperti Pasal 2 ayat (1), Pasal 2 ayat (2) ini tidak diberikan penjelasan dan anotasi "jelas" yang menunjukkan maknanya

${ }^{35}$ K.H. Ma'ruf Amin, Ketua Panitia Pengarah Ijtima' Ulama Komisi Fatwa MUI se Indonesia II. Lihat www.hukumonline.com.

36 Soetojo Prawirohamidjojo, Pluralisme Dalam Perundang-Undangan Perkawinan Di Indonesia, (Surabaya: Airlangga University Press, 1986), h. 140. 
sudah jelas oleh pembuat undang-undang. Ini menunjukkan dua hal: pertama, pasal ini tidak jelas maknanya; kedua, terdapat keraguan para pembuat undang-undang terhadap wajib atau tidaknya pencatatan perkawinan. Dengan demikian, Pasal 2 ayat (2) ini tidak membawa konsekwensi hukum terhadap pencatatan perkawinan. Dalam hukum, sebuah klausul baru dapat dipandang sebagai sebuah norma hukum yang dapat memberi konsekwensi hukum terhadap suatu perbuatan hukum apabila memuat kata-kata wajib/harus, dilarang/tidak boleh, atau boleh. Sementara Pasal 2 ayat (2), tidak menganndung salah satu dari kata-kata itu. Karena itu, bukan merupakan perbuatan melawan hukum bagi pasangan yang melakukan perkawinan bawah tangan.

Yang menjadi masalah bagi sebagian orang selama ini, terutama mereka yang menganggap bahwa perkawinan bawah tangan tersebut dilarang atau tidak halal, adalah dampak negativnya bagi para pihak, anak, dan harta bersama kalau salah satu pihak (pihak yang dominan dalam rumah tangga) tidak bertanggungjawab atas perkawinannya. Bagi mereka, perkawinan bawah tangan "tidak dapat dibuktikan adanya" sehingga salah satu pihak yang tidak memiliki kejujuran dapat menghindar dari tanggungjawabnya terhadap pihak lain, baik mengenai anak maupun harta bersamanya.

Namun sejak tahun 2005, masalah tersebut sudah bukan masalah lagi, sejauh mengenai perkawinan bawah tangan, bukan "kumpul kebo". ${ }^{37}$ Untuk membuktikan terjadi atau tidaknya, ada atau tidaknya perkawinan bawah tangan, dapat dibuktikan dengan bukti lain jika suami atau isteri tidak mempunyai akta nikah. Yurisprudensi Mahkamah Agung RI Nomor 57 K/Pdt/2005 tanggal 29 Mei 2005 mengatakan bahwa sungguhpun penggugat dan tergugat tidak mempunyai bukti perkawinan (akta nikah) akan tetapi terdapat petunjuk keduanya hidup bersama seperti layaknya satu keluarga yang dibuktikan dengan Kartu Keluarga sehingga mereka seperti suami isteri. ${ }^{38}$ Ini adalah kaidah hukum yang disebut kaidah hukum yurisprudensi, yaitu kaidah hukum yang lahir dari pengadilan, sesuai dengan fungsinya sebagai jude made law, yang posisinya sederajat dengan kaidah hukum lainnya. Dengan demikian, untuk membuktikan bahwa suatu perkawinan pernah terjadi atau ada bagi pasangan suami-isteri yang melakukan perkawinan bawah tangan, dapat dilakukan melalui Kartu Keluarga saja. Dari sini dapat disimpulkan bahwa perkawinan bawah tangan menurut hukum nasional Indonesia merupakan perkawinan yang dibenarkan atau legal pula.

${ }^{37}$ Istilah "Kumpul Kebo", tidak ada dalam kepustakaan hukum nasional Indonesia, tetapi istilah itu lazim digunakan dalam pergaulan masyarakat Indonesia sehari-hari, untuk menunjukkan adanya hubungan sebagaimana layaknya suami-isteri antara seorang laki-laki dan seorang perempuan tanpa ikatan perkawinan yang sah. Oleh masyarakat Indonesia, hubungan yang demikian disamakan dengan berkumpulnya binatang, kerbau (Jawa: kebo).

${ }^{38}$ Baca Yurisprudensi Mahkamah Agung RI Nomor 57 K/Pdt/2005 tanggal 29 Mei 2005. 


\section{KESIMPULAN}

Berdasarkan uraian mengenai perkawinan bawah tangan pada bagian yang lalu, dapat ditarik kesimpulan sebagai berikut:

1. Perkawinan bawah tangan, adalah perkawinan antara seorang laki-laki dan seorang perempuan, yang terpenuhi rukun-rukun dan syarat-syarat yang ditetapkan dalam hukum agama masing-masing dan peraturan perundangundangan, namun tidak dicatat pada instansi pemerintah yang berwewenang, yakni Kantor Urusan Agama (KUA) Kecamatan bagi orang yang beragama Islam atau Kantor Catatan Sipil (KCP) bagi orang yang beragama selain Islam.

2. Hukum nasional Indonesia, adalah keseluruhan norma hukum dan aturan hukum yang kait-mengait satu sama lain yang bersumber dari Pancasila dan UUD 1945, yang berlaku terhadap seluruh rakyat Indonesia dan di seluruh wilayah Indonesia. Keseluruhan norma dan aturan hukum tersebut dalam implementasinya diwujudkan dalam beberapa bentuk yaitu undang-undang, yurisprudensi, kompilasi, dan fatwa.

3. Status hukum perkawinan bawah tangan, baik dilihat dari sisi agama maupun peraturan perundang-undangan, adalah merupakan perkawinan yang dibolehkan/legal menurut hukum nasional Indonesia, sehingga mengikat para pihak yang melakukannya dan berakibat hukum terhadap anak dan harta benda dari perkawinan itu.

\section{Daftar Pustaka}

\section{Buku}

Abdurrahman. Himpunan Peraturan Perundang-Undangan tentang Perkawinan. Cet. I; Jakarta: Akademika Pressindo, 1986.

Bruggink, JJH. Rechtsreflecties, Grondbegrippen uit de Rechtstheorie, diterjemahkan oleh Arief Sidharta, dengan judul: Refleksi Tentang Hukum. Cet. II; Bandung: PT. Citra Aditya Bakti, 1999.

Daud Ali, Mohammad. Hukum Islam: Pengantar Ilmu Hukum dan Tata Hukum Islam di Indonesia. Cet. XVI; Jakarta: PT. RajaGrafindo Persada, 2011.

Djamali, R. Abdoel. Pengantar Hukum Indonesia. Edisi Revisi/Cet. XVII; Jakarta: PT. RajaGrafindo Persada, 20011.

Hadikusuma, Hilman. Hukum Perkawinan Indonesia. Bandung: Mandar Maju, 1990.

Kartohadiprodjo, Sudiman. Pengantar Tata Hukum di Indonesia, Jilid I. Jakarta: PT. Pembangunan, 2004.

Poerwadarminta, W.J.S. Kamus Umum Bahasa Indonesia. Jakarta: Balai Pustaka, 1985. Prawirohamidjojo, Soetojo. Pluralisme Dalam Perundang-Undangan Perkawinan Di Indonesia. Surabaya: Airlangga University Press, 1986. 
Purbopranoto, Kuntjoro. Hak-Hak Azasi Manusia dan Pancasila. Cet. V; Jakarta: Pradnya Paramita, 1976.

Ramulyo, Mohd Idris. Hukum Perkawinan, Hukum Kewarisan, Hukum Acara Peradilan Agama dan Zakat Menurut Hukum Islam. Cet. III; Jakarta: Sinar Grafika, 2004.

Saleh, K. Wantjik. Hukum Perkawinan Indonesia. Cet. IV; Jakarta: Ghalia Indonesia, 1978.

Siddik, Abdullah. Hukum Perkawinan Islam. Jakarta: Tinta Mas Indonesia, 1983.

Sidharta, Bernard Arief. Refleksi Tentang Struktur Ilmu Hukum (Sebuah Penelitian Tentang Fundasi Kefilsafatan dan Sifat Keilmuan Ilmu Hukum Sebagai Landasan Pengembangan Ilmu Hukum Nasional Indonesia). Cet. II; Bandung: Mandar Maju, 2000.

Sunaryati Hartono, CFG. Politik Hukum Menuju Satu Sistem Hukum Nasional. Cet. I; Bandung: Alumni, 1991.

\section{Artikel}

http://www.mui.or.id: Fatwa MUI.

Jaspan, MA, "Mencari Hukum Baru: Sinkretisme Hukum di Indonesia yang Membingungkan", dalam Mulyana W. Kusumah dan Paul S. Baut, Hukum, Politik dan Perubahan Sosial, (Jakarta: Yayasan Lembaga Bantuan Hukum Indonesia, 1988.

KH.Ma'ruf Amin, www.hukumonline.com.

Kodiran, "Aspek Kebudayaan Bangsa dalam Hukum Nasional", dalam Artidjo Alkostar (ed.), Identitas Hukum Nasional, (Yogyakarta: Fakultas Hukum UII, 1997.

Sularno, M, “Syari'at Islam dan Upaya Pembentukan Hukum Positif di Indonesia”, dalam Majalah Al-Mawarid, Edisi XVI, Tahun 2006.

\section{Peraturan Perundang-undangan}

Mahkamah Agung RI. Yurisprudensi Nomor 57 K/Pdt/2005 tanggal 29 Mei 2005.

Undang-Undang Nomor 1/PNPS/1965.

Undang-Undang Dasar 1945.

Undang-Undang Nomor 1 Tahun 1974 Tentang Perkawinan. 